\title{
Body of Woman As A Site For Battle: A Critical Study of Sidhwa's Ice-Candy Man
}

\author{
* Dr. Shamshad Rasool, Lecturer \\ ** Dr. Raza-E-Mustafa, Assistant Professor \\ *** Dr. Zahoor Hussain, Lecturer (Corresponding Author)
}

\begin{abstract}

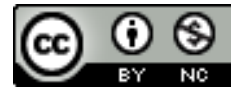

Partitioning of the subcontinent into Pakistan and India is a mega event in the history of South Asia that haunts the minds of the inhabitants because of the untold destruction and the atrocities inflicted on the migrants. The later generations come to know of the havocs carved on women's bodies mostly through stories of the victims or who witnessed molestation of women. In this connection, this article aims to critically analyze the novel Ice-Candy Man by Sidhwa which delineates the defilement of women at the periphery. The views of different feminist critics constitute the theoretical framework while Fairclough's social discourse model serves as a methodological framework. For analysis, the technique of Content Analysis has been employed. The findings reveal that Sidhwa has caricatured the predicament of the women whose bodies became sites for male aggression as icons of the ethnic groups during the communal strives. They undergo physical and sexual furiousness of men before, during, and after the partition. Men dehumanized them to disgrace the opponents/the other. The novel may, further, be studied from psychoanalytical, cultural, and Marxist perspectives.
\end{abstract}

Keywords: Communal Strives, Body, Dehumanized, Ethnic Groups, Icon, Molestation, Partition.

\section{Introduction}

Maltreatment of women in war circumstances is perpetual. Skjelsbæk (2006, p. 3) avers that "history has shown us that the female body is an extension of the battlefield". At this battlefield, victory and vengeance are performed on women's bodies by the victor and soldiers (Rasool, 2009). They suffer agony, and the most common is sexual torture by the victor.

The war justifies the power of rape and it is carried out with liberty. The power of the offenders is because the victims do not delineate the experiences they undergo but prefer to remain silent. Pennebaker (2000) states that social taboos, matters of shame, and the fear that they may be abandoned by their family and the community and force the rape victims to be silent. Women who experience such ordeals admit victimization when it too late to measure the impact the rape on them.

The subcontinent underwent an unprecedented experience of decolonization in 1947; the splitting up of British India into two sovereign states. Mass migration brought dreadful havoc for the inhabitants, women were the worst victims. In history, the calamity of women remained untold. However, the writers did their job to fill up the gap. They portrayed their humiliation. Sidhwa is also one of them who has tried to give voice to their catastrophes. She delineates the symbolic defilement ongoing with them on each side of the border (Wilder, 2004). She laments at the division engraved on the body of women as they were bruised, mutilated, raped, looted, and forced to dance naked. Sidhwa seems to be preoccupied with the event of partition and its havocs. She points to it in almost all of her novels. She states; ". . . the ominous roar of the distant mobs was a constant of my awareness, alerting me, even at age seven, to a palpable sense of the evil that was taking place in various parts of Lahore" (Sidhwa, 2000).

\section{Purpose of the study}

This study aims at critically analyzing the novel Ice-Candy Man to find out, considering literature as the reflection of society, why women are targeted, and what predicament their bodies suffer as an extension of the battlefield in tumultuous situations. Though the riots ensue unannounced, they transform into the war between ethnic groups due to religious and communal intolerance. The women are an obvious target of the opposite community as they are considered the icon of honor. It also

\footnotetext{
* Department of English, University of Gujrat, Gujrat Email: shamshad.rasool@uog.edu.pk

** Department of English, University of Gujrat Email: razaemustafa@uog.edu.pk

*** BZU Layyah Campus, Layyah Email: zahoor_linguist@bzu.edu.pk
} 
focuses on examining the factors which, ironically, establish them as an icon of honor though are not given honor in the domestic and social setup.

\section{Research Questions}

The following research questions have been designed which are denominators of the purpose of the study:

1. What are the factors which make women icons of religious or ethnic groups in Ice-Candy Man?

2. Why do the bodies of women become an extension of the war field in the novel?

3. What atrocities do the female characters in Ice-Candy Man undergo as targets of the opponent groups?

\section{Literature Review}

Writing on partition depicts the postcolonial trend of Sidhwa. She blames no ethnic group but imperialism. At that time, people were not clear about the manifestoes of the political parties. For example, Lenny's description of the leaders is vague. She does not like the comments of Ice-Candyman as sometimes he quotes Gandhi and the other time Nehru. He also supports the views of Jinnah. In her accounts, she explains that all the calamities Hindu, Muslim, and Sikh had to suffer were the conspiracy of the imperial Raj. The British ruled the region through 'divide-and-rule (Sidhwa, 1989, p. 63) policy. While quitting India, they divided it into two to provide themselves an opportunity to meddle in the future affairs of the supplanting countries. Hobsbawn (1994, p. 219-20) also has the same view and states that "It was a war (Second World War) that broke India into two. In one sense it was the last great triumph of the Raj - and at the same time its last exhausted gape."

Butalia (2006, p. 178) observes that the generation after the partition has come to know of this mega through the stories of those who live across the borders. History is unable to inform them. It is pertinent to mention that the natives in British India were living in peace before the partition. There are many instances of the social and fraternal relations between the Muslims and the Sikhs. For example, the inhabitants of Pir Pindu in Ice-Candy Man (Sidhwa, 1989) and Mano Majera in Train to Pakistan (Singh, 2006). The inhabitants in the servant quarters in Lenny's home belonging to different religious and ethnic groups also have complete harmony.

With the declaration of the division of Punjab and Bengal, people begin to dwindle into religious symbols (Sidhwa, 1989). Everyone becomes himself. The center loses its hold and anarchy prevails. Friends become foes. Everyone is in a religious frenzy; the religion of one ethnic group turns to be poisonous for the other. Lenny narrates the calamity prevailing over Lahore as she feels that the world is flaming. She says, "I think my flesh and clothes will catch fire. I start screaming: hysterically sobbing" (1989, p. 137).

The writers have documented the defilement of women during the partition to give voice to the prevailing silence in literary and non-literary writings representing the atrocities played on the bodies of women as 'battle fields'. As Bahri (1999) says that literature can fill up gaps, literary figures wrote about partition and caricatured the plight and displacement of women. There are hundreds of instances of rape and abduction. People lost their dignity and memory. The loss of dignity and the instances of rape are the foremost characteristics of the Partition. Historians have written a lot about India's partition in the context of drastic political upheavals (Rasool, 2009). It is a pity that there is silence about the predicament of women who were the worst victims. Antagonistic relations between Pakistan and India since the declaration of partition worsened the situation. In the rift of two states, women's stories were practically forgotten.

Bahri (1999) comments that, in Ice-Candy Man, Sidhwa has told the story of partition from the female perspective and about the unique price women had to pay during and after partition. Menon and Bhasin (2006) have termed the tales of partition, 'gendered narrative of displacement and dispossession, of large-scale and widespread communal violence...' (p. 210). According to Rasool (2009), the most detestable aspect of partition is raping, molestation, and dishonoring of women who were not part of the decision-making process of partition. The question arises why men from both communities turned against women of the opposite side. It was, perhaps, because of the patriarchal structures which lie in the foundation of history (his/story) as a discipline. According to Pennebaker (2000), by dishonoring another's daughter, wife, or sister, one feels elated. He ridicules other's religion and personal honor. As women are always considered property of men and 'icons of honor' throughout history, regarding war affairs, they remain at the receiving end of violence (Rasool, 2009). 
Butalia (1999) is also in the same line when she writes, that, at the time of communal violence, women are essentially at the receiving end as victims, but they are assigned a role of rebuilding and reconstructing the community. Graeber (1991) observes that a woman's body is a site for vengeance and celebration of victory as it has happened in the world. Perhaps, the realization of such persecution during and after the partition instigated Sidhwa to start a struggle for the rights of women.

Historical documents and literary works reveal that many suicides were committed on both sides during the partition to preserve their chastity. Butalia (2006) narrates an incident of collective self-immolation of ninety women at Thao Khalsa who jumped into a well. They piled the beddings and cots to set fire and jumped into the flames. Singh writes: 'women killed their children and jumped into wells that filled to the brim with corpses' (2006, p. 200). Sidhwa has narrated the incident of Pir Pindu. But the question is why women decided to kill themselves at Pir Pindu or Thao Khasla or any other place.

Mr. Gandhi also suggested that, sometimes, suicide is preferable to compliance (Singh, 2006, p. 89). Butalia also has the same view. She writes that it is perceivable that women would have consented to commit suicide to the dignity of the community because they had been taught and trained that chastity more valuable than life. Therefore, they offered themselves for immolation as they were also supposed to do so by their men. In Train to Pakistan when violence and selfimmolation are reported to Hukam Chand, he exclaims that the ir women are "so pure that they would rather commit suicide than let, 'a stranger touch them" (Singh, 2006, p. 20).

One view is that they did so to avoid kidnapping, the brutality of the opposite frantic group, and preserve their honor or sanctity. Menon and Bhasin (2006) opine that they saved their honor by self-immolation because the kidnapped were forced to convert and erode their identity. To uphold their identity, they preferred death to humiliation at strangers' hands.

The view is that the seclusion of women from social life by patriarchy made their bodies the property of men. For example, Singh addresses women concerning property/material things; "one should never touch another's property; one should never look at other's woman, one should just let others rake one's goods and sleep with one's sister" (2006, p. 119). While defending the Muslims of Pir Pindu that they are not guilty of the trains full of imputed bodies from Pakistan, he pleads that they have neither expelled them from their homes nor seduced their women. The narrative shows that women are equal to the property of men and that they have to protect the property from any harm and keep it intact.

The foregoing discussion reveals that there is a need to investigate the atrocities inflicted on the bodies of women in the tumultuous situations as a site for war because many studies have not been conducted on the literary works to explore this issue. Therefore, this study has been conducted to explore why and what happens to women in violent conditions as Sidhwa has caricatured the nature of men from both sides of the border. Thus, this study is a genuine contribution in the arena of feminist studies; it may open a new horizon for the researchers working on literary works.

\section{Methodology}

The study is a critical analysis of the writer's stance that she has delineated in the novel using the prevailing discourse in the patriarchal society. Being a qualitative study, the data would consist of words, sentences, ideas, and themes. The qualitative approach takes into account the "subjective interpretation of the content of text data" (Hsieh \& Shannon, 2005, p. 1278). Therefore, it requires intensive reading to identify the shred of evidence as the language of a text contains the approach of the writer. Therefore, Content Analysis is a suitable technique for the present study. According to Krippendorff (2012, p. 24), it is employed to make "replicable and valid inferences from texts (or other meaningful matter) to the contexts of their use".

\section{Frame work}

This study is a critical analysis of the selected novel and aims at identifying, implicit/explicit, the reason why bodies of women become an extension of a battlefield in the resentful situation. It focuses, as Fairclough $(2001$, p. 4) pinpoints, to arise "consciousness of exploitive social relations, through focusing upon language". Therefore, Fairclough's (2001) approach of social discourse outlines the framework for this study. It is a tri-aspectual framework. The aspects are:

1. Description of the text,

2. Interpretation of relationship between text and interaction,

3. Explanation of the relationship between text and social context. 
The application of the three levels in this study has been explained in the following subsections.

a. Description of Text

The primary dimension of the model is discourse-as-text. This level analyses the linguistic features used in the contents of a text; the use of vocabulary, wording, use of metaphor, grammar, sentence and text structures, and cohesion. Further, the analysis of the intertextuality which links a text to other certain texts is also an important element of analys is at this stage. In the present study, the description of the text refers to the identification of various pieces of evidence of social constructions embedded in the language used in the novel.

b. Discursive practices

The second stage is discourse as discursive practice. It takes into account various aspects of the production, reception, and consumption of a text. Some aspects play a more institutional character as compared with others (Fairclough, 1995). At this level, an attempt has been made to make out factors that are involved in the selection of language by the author, and the possible repercussions. It also includes an ideological assumption about the bodies of women as icons of honor in the milieu.

c. Social practices/Explanation

The last aspect of the model is discourse as a "form of social practice" (2001, p. 14). It takes into account the ideological, social, and hegemonic practices rampant in society as well as how such practices shape discursive practices or they are shaped by them. Social practices reflect reality and influence social structures as well. It also explains the role and contribution of social practices and institutional structures in establishing ideology about women as icons of honor. This model has been explained in the figure given below:

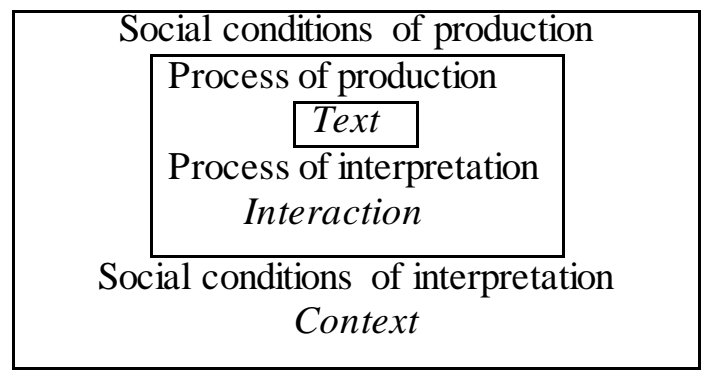

Fig 1: Discourse as text, interaction, and context (Adopted from Fairclough, 2001).

To conclude, it is pertinent to mention here that the three aspects of analysis overlap doing an analysis. This model considers the role of the discursive practices involved in the process of making women icon of an ethnic group and laying responsibility on their men to defend them, and the social practices that have contributed to the production and perception about the identity of women, and the attributes associated with them. Combining the levels of analysis has significantly helped in pinpointing how and why the female bodies are mutilated as icons of honor.

\section{Discussion and Findings}

Sidhwa portrays the victimization of women through vignettes: Lenny's second ayah, Hamida, a fallen woman, and the implanted story of the narrative of Rana. Sidhwa gives voice to the mayhems committed against women in a culture that persists in silencing such voices to save its honor (Bahri, 1999).

Sidhwa informs the readers of the dangers of placing women in this 'iconic' position. The character of Ayah symbolically raises this question. At the outset of Ice-Candy Man, she has been presented as a figure that can consolidate different ethnicities and religious groups together. As Lenny's keen eyes tell us, "Hindu, Muslim, Sikh, Parsee are, as always unified around her" (p. 105).

With the geographical division, they begin dwindling into symbols. Ayah, like so many sufferers on each side of the boundary line, becomes a 'site' for men to take out their aggression against the culture, ethnicity, religion, and nationality of each other. Sidhwa writes, '. . . however, partition turns Ayah's sexuality against her' (p. 105). In the end, Ayah is taken away by a Muslim mob. She was betrayed by the man who claimed to love her.

Lenny narrates that a train from Gurdaspur arrived. Ice-Candy-man was expecting his family in it. When he peeped into the compartments, he found the mutilated corpses only. The implication was that it was the result of the brutality of the Sikhs or the Hindus. The most horrible fact was that 
'There are no young women among the dead! Only two gunny bags full of women's breasts! (p. 149). The narrator gives an account of the attack of a Sikh mob on the train. Sikandar, the father of Zaitoon, attacks a Sikh who was holding the one breast of a woman. The narrator narrates: "She is screaming . .. frantically waving her arms, the woman is swept away" (Sidhwa, 1993, p. 231).

Physical and sexual violence against women is symbolic as the reader can see the 'women' were reduced to the level of 'mere a body'. The mutilation of the 'body' is also symbolic because it is not merely the maiming of the body parts but an attack on the force that 'nurtures' and, thus, destruction of the force that gives life to the nation (Rasool, 2009). Further, it desexualizes a woman and denies her the role of a wife and a mother. And, consequently, she becomes an outcast, barren, fruitless, and freakish body. It incorporates the desire to eliminate the rival from the earth (Bahri, 1999).

This heinous act of cutting breasts and killing his sister and his mother enraged Ice-Candyman to perpetuate the same act on Hindu or Sikh women. Such retaliation is, in fact, the cause of all the molestation on both sides. One group strives to revenge from the 'other'. He declares, "I want to kill someone for each of the breasts they cut off the Muslim women" (p. 166). His act of abduction and desecration of Ayah indicates his disdain for India and the Indian community.

Sidhwa writes that different religious groups who were living in India in peace for centuries turned against one another. In pursuit of persecuting and disgracing the opposite, they particularly targeted the womenfolk of the other side. But if one ponders over it, one can know that only women were turned to be the 'Other'. Sidhwa (1989) declares the fact concerning Ayah that, ". . . however, partition turned Ayah's sexuality against her" (p. 97). The adorers of Ayah abandon her and assume her the symbol of the rivals. A worth noting point is that no woman from the Parsee community was victimized during the anarchy as the community had decided to remain neutral and 'hunt with the hounds and run with the hare' (p. 16).

Lenny narrates the women's mutilation of Pir Pindu. When Rana awakes under the corpses, he hears "great anguish sobs- and at intervals, she screams: 'you'll kill me! Hai Allah . . . Y'all will kill me!' (Sidhwa, 1989, p. 202). Rana hears intolerable shrieks and moaning of women in great anguished sobs coming from the mosque. He is sure he heard the cries of his Mother, Chidda's voice. The Sikhs rejoice at their body saying, 'Wah Guru! Wah Guru'! On the whimperings, a man says irritably, 'stop whimpering, you bitch, or I'll bugger you again!' (p. 203).

Rana also saw the brutality committed against women along the way during his escape; 'he saw babies, snatched from their mothers, smashed against walls and their howling mothers brutally raped and killed' (p. 207). Their molestation was evident everywhere; 'he saw a naked woman, her light Kashmiri skin bruised with purple splotches and cuts, hanging head down from a ceiling fan. ... Jeering men set her long hair on fire' (p. 207). The oppressors were mocking her.

The mobs undressed the young girls, made them parade naked and raped in a gang. Rana sees his eleven years old sister, Khatija, 'run stark naked into their courtyard, her long hair disheveled, her boyish body bruised, her lips cut and swollen, and a bloody scab where her front teeth were missing' (p. 200).

The shreds of evidence illustrated above reveal that physical and sexual oppression against women had run rampant during partition because every religious and ethnic group was satiating its hunger by taking revenge on women's body which took the form of a battlefield.

The obvious oppression that women experience is sexual assault from the men of the other community. Dishonoring other's wife, sister, and mother are taken as a stigma for the opposite for failing to protect his property (Pennebaker, 2000). That's why Ayah is prostituted by Imam Din, Yousaf, Pathan, cousin's cook, and Ice-Candy-man. However, it is Ice-Candy-man who also uses her as a prostitute.

Sidhwa shows that dishonoring other's womenfolk is rampant in the subcontinent in the routine conflicts as well. It intensifies during the commotion. Lenny tells us dishonoring of women by Sher Singh who hires his brothers, cousins, and Ice-Candy-man to get his house evacuated. The gang called them names and made "Hulla Gulla outside the building" (p. 122). The male tenants were not at home. They shouted and called them to appear in the windows, "pretty ladies: don't hide. We have something to show you". Being sure that they had attracted the attention of the women peeping through windows, they exposed themselves to the ladies, as Ice-Candy-man says, "in such a way as to shield our rears: and in front our dangling dingdongs' (p. 123). Terrified women started screaming. 
The narrator further tells about the disgraceful behavior with the women: 'but what a Hulla Gulla! The women screamed and cursed . . you'd have thought we'd raped them'! (p. 123).

Treatment of the tenants' women has a background. It is a reaction to the similar behavior with women of Sher Singh's family as the tenants had "Exposed themselves to his womenfolk! They went a bit further . . . played with one of Sher Singh's sister . . . Nothing serious-but her husband turned ugly ..." (p. 156).

It is not difficult to surmise that women are maltreated in the time of mayhem as 'icons of honor', and that the opposite communities clash with them. Women seldom partake in such a fuss. They remain, as Butalia (2006) says, at the receiving end of violence for the fault they do not commit.

Another form of violence that Sidhwa highlights is self-immolation. Women committed suic ide to safeguard their chastity, to avoid sexual oppression, and to preserve their sanctity and honor of the family, nation, and religion. Suicides were committed, sometimes, individually, and, sometimes, collectively.

Sidhwa (1989) narrates the plan for self-immolation of the women of Pir Pindu that was to take place in case of an attack of the Sikh mobs. At the news that an invasion by the Sikhs is imminent, women wail and suggest that children and young girls should be transferred to some safe place to protect them from any brutality as they were horrified by the singling out of women taking place in the nearby villages because the survey party had reported about the Sikh mob: 'They are. ... Parading Muslim women naked through the streets - raping and mutilating them in the center of villages and mosques' (p. 197).

Such maltreatment was a threat to the chastity and honor of the Muslim community. So they decided on self-immolation. To avoid the impending brutality, they would set themselves on fire with the kerosene oil that was provided to them. Another view is that it was because they had no option, and they were bound to do so. Sidhwa (1989) gives a valid view that it was decided to be immune from the brutality of the rabble.

Sidhwa highlights the reason for committing suicide: when Ayah is brought to the camp and children call Ayah from the parapet, the fallen women thrash the ir breasts and cry, "Hai! Hai! Hai! Hail' reflecting the history of their cumulative sorrows of their Muslim, Hindu, Sikh and Rajput greatgrandmothers who burnt themselves alive rather than surrender their honor to the invading hordes besieging their ancestral fortresses" (pp. 273-4).

Committing suicide was a valid decision for the time being as the women who failed to burn themselves suffered more humiliation and agony than death; "those who did not commit suic ide were paraded naked in the streets, raped in public, and then murdered" (Singh, 2006, p. 106). Therefore, they found sanctuary in death for then 'the natural protectors' had failed to defend the ir chastity; Rana hears moaning of a woman 'Do anything you want with me but don't torment me,' . . for God sake, don't torture me!' . . O Oh God" (p. 200). Such a portrayal of a woman in Open Up reveal the nature of violence.

Women in the subcontinent are eulogized as 'mother', for example, mother India; "she is constructed as the symbol of honor in the role of wife, sister, mother and daughter though she does not enjoy any respectable place in the family (Rasool, 2009). Sidhwa (1989) has pointed out that women in Hindu, Sikh, and Islam remain confined to their homes and domestic affairs in the name of Purdah - veil. Purdah, 'the seclusion and segregation, is imposed on women to protect them from the strangers.' Any mention of her before the stranger is taken as if it will pollute her. For example, in The Bride, in the refugee camp when Nikkah Pehlwan asks Qasim about his wife if she is dead, Qasim storms up and glares at him and threats: 'Look . . . nothing about my wife concerns you. ...' (1993, p. 237). He further warns him and exclaims: "you don't ask a hill-man anything about his womenfolk, understand" (p. 237). The same idea becomes evident when Miriam addresses Qasim through her husband Nikkah. She says to him, 'ask your friend if he would like to have this chapatti (p. 239). Similarly, when Kalyani meets Narayan she avoids talking to him directly because tradition hampers her doing so. Sidhwa writes in Water (2006, p. 64) 'Kalyani, prohibited by tradition from addressing a stranger directly, spoke to Narayan through Chuyia'. In Ice-Candy Man (1989) when Lenny asks IceCandy-man questions about his wife, Ayah forbids her and says that 'men don't like so much discussion about their womenfolk' (1989, p. 125).

Sidhwa spells out the fact that patriarchy has excluded the desolate creature from social life. Not to speak of social life they don't have any role in their discussion. They are cut off from society in 
the name of "Ghairat"-honor; they are forced to be veiled or covered in purdah which indicates the role women are supposed to play in the milieu (Pennebaker, 2000). Perhaps, this very tradition caused imputation and predicament for women during the partition.

Sidhwa observes through her novel that pains and sufferings are experiences that the social order constructs. The construct of the patriarchal society results in further victimization of women, as demonstrated through the character of Hamida - who blames her fate for what has happened to her, never questioning the "men" who have betrayed her - first by abducting her and later by disallowing her to come back to her family! The same is true for Ayah who was betrayed first by her adorers and, later; she is made to carry the burden of shame. Both were reduced to mere bodies.

The betrayal of Ayah and Hamida symbolically exposes Sidhwa's rejection of social and patriarchal structure that insists on forgetting and silencing. Rehman (1999) says that Sidhwa makes each of us witness the gendered narrative of female oppression and subjugation.

\section{Conclusion}

The analysis of Sidhwa's text shows that the 'iconic' position of women deflates her. In the insurgence of partition, they were particularly targeted by the opposite community to humiliate the one they belonged to. Women were victimized, sexually assaulted, and disgraced for their no-fault but patriarchal underpinnings about the honor of the community linked with them. They were not part of the brawl and its backdrop because the partition was decided by men. But men assaulted them from both sides of the boundary.

They were not part of the riots. Though they had no slipup, they faced brutality. They were at the receiving end. They were forced to parade naked. They were raped in succession before the men of their family. Ayah was debased by Pakistani Muslims in reaction to the mutilation and rape of women in the train that arrived from Gurdaspur - India. The Indians made off with young women and girls. Their breasts were cut off and put in two gunny-sacks. Ice-Candy-man dehumanized and demoralized Ayah to avenge the molestation of his sister and mother. He won his previous lustful love also in the guise of revenge. In both cases, Ayah was victimized due to the ill-intentions of men as Ice-Candy-man took her off with him to the brothel and prostituted her and earned money. Companionship and close contacts of the past had nothing to do. He solaced the flaring sentiments of revenge from the Indians and he also succeeded in exploiting Ayah lustfully. All the acquaintances prostituted her when they got a chance. Hamida was disgraced by the Indian Sikhs. It might also be a reaction to any of the many tragedies that took place somewhere.

To target women is not exclusive to battles but it happens even in the normal social life when a tussle originates among men. For example, the debasement of women in the description when Sher Singh gets his house evacuated by the tenants who have performed the same trick with the women of Singh's family.

It can be concluded from the instances illustrated above that women have always been targeted as the other. Their iconicity brings untold mishaps.

Having gone through these brutalities, women deserved sympathies but they were discarded by their men and families. They should not remain silent and submit to the ir degradation. A community like Sidhwa should raise a voice to the sufferings of the voiceless women who suffer during such commotions and are discarded afterward.

The text of the novel is rich with valuable ideas. It invites further studies from Marxist, cultural, psychoanalytical, and postcolonial perspectives. It has vividly exhibited the Lahori culture. It may be explored.

\section{References}

Bahri, D. (1999). Telling tales: Women \& the trauma of partition in Sidhwa's cracking India. Interventions: International Journal of Postcolonial Studies, 1 (2), 217-34.

Butalia, U. (2006). Community, state \& gender: Some reflections on the partition of India. In Hassan, M. (Ed.), inventing boundaries: Gender, politics \& the partition of India (pp. 178-207). New Delhi: Oxford University Press.

Fairclough, N. (1999) Linguistic \& intertextual analys is within discourse analysis. In A. Jaworski, \& N. Coupland (Eds.), the discourse reader (pp. 183-212). London: Routledge.

Fairclough, N. (2001). Knowledge \& power ( $2^{\text {nd }}$ Ed.). London: Longman.

Graeber, L. (1991, Oct., 6). [Review of Cracking India]. The seeds of partition. The New York Times. Hobsbawn, E. (1994). Age of extremes: Short twentieth century 1914-1991. London: Michael Joseph. 
$\overline{\text { Hsieh H. F., \& Shannon, S. (2005). Three approaches to qualitative content analysis. Qualitative }}$ Health Research, 15(9), 1277- 1288.

Krippendorff, K. (2012). Content Analysis: An introduction to its methodology ( $3^{\text {rd }}$ Ed.). London: Sage Publications, Inc.

Malmberg, J. L. (2001). [Review of Ice-Candy Man] Voices from the Gaps: Women writers of color. Postcolonial studies at English department of Emory University. Retrieved Nov. 26, 2019, from, www. Emory.edu

Manto, S. H. (1987). Kindom's end \& other stories. (Trans. K. Hussain). New Delhi. Penguin.

Menon, R., \& Bhasin, K. (2006). Recovery, rupture, resistance: The Indian state \& abduction of women during partition. In M. Hassan (Ed.), Inventing Boundaries: Gender, politics \& the partition of India. New Delhi: Oxford University Press.

Pennebaker, M. K. (2000). The will of men: Victimization of women during India's partition. Agora, l(1), unpaged.

Rasool, S. (2009). The postcolonial feminist approach in Sidhwa's works. Unpublished, M. Phil dissertation, Bahauddin Zakariya University, Pakistan.

Rehman, T. (1999). A history of English literature in Pakistan. Lahore: Vanguard.

Sidhwa, B. (2006). Water. Karachi: Oxford University Press.

Sidhwa, B. (2000). Interview with Bapsi Sidhwa by Julia Rajan. Monsoon magazine. Retrieved June 23, 2020, from, http $/ /$ www.monsoonmag.com/interviews/

Sidhwa, B. (1993). The bride. Karachi: Oxford University Press

Sidhwa, B. (1989). Ice-Candy Man. New Delhi: Penguin Books.

Singh, K. (2006). Train to Pakistan. India: Roli Books.

Skjelsbæk, I. (2006). Voicing Silence: A political psychological analysis of the aftermath of the Bosnian war rapes. Unpublished, Ph.D. thesis. Norwegian University of Science \& Technology.

Wilder, J. (2004). Bapsi Sidhwa. Postcolonial Studies at English department of Emory University. Retrieved December 6, 2019, from, www. Emory.edu 